\title{
Further remarks on the deflexion and grammaticalization of the Old English past participle with habban
}

\author{
JAVIER MARTÍN ARISTA \\ Universidad de La Rioja (Spain)
}

Received: 22/10/2019. Accepted: 06/05/2020.

\begin{abstract}
This article deals with the transitive construction involving habban and the past participle in Old English, and focuses on the loss of the adjectival segment of the participial inflection. The analysis is based on data retrieved from the York-Toronto-Helsinki Parsed Corpus of Old English Prose. Inflectional morphology and constituent order, including the relative and the absolute position of the past participle, are considered. The data indicate that the reanalysis the habban+past participle construction is nearly over by the end of the period.
\end{abstract}

KEYWORDS: Old English, participle, habban, deflexion.

\section{AIM AND SCOPE}

The Old English past participle can be found in two constructions, one involving the past participle and the verb habban 'to have' and the other comprising this non-finite form of the verb and the copula bēon 'to be'. In both constructions, the non-finite form can be inflected as adjective. Of the two constructions, the past participle with bèon has drawn more attention, above all from the perspective of the grammaticalisation of the passive.

Regarding the past participle with habban, Ringe and Taylor (2014: 435) support the view "that a non-adjectival reading of HAVE+PPLE is already in place in the earliest OE

*Address for correspondence: Universidad de La Rioja, Departamento de Filologías Modernas. Logroño 26004, Spain; e-mail: javier.martin@unirioja.es 
texts, i.e. that OE has a periphrastic perfect with auxiliary HAVE." On the inflection of the past participle with habban, these linguists point out that "none of the authors that discuss this issue lay out an objective way to distinguish these cases, nor provide any frequencies" (Ringe \& Taylor, 2014: 436, ft. 16-17). A study in the question that makes reference to specific authors and texts is also pending. Martín Arista and Ojanguren López (2018a, b) conduct a corpus-based study on the participle with bèon 'to be' that puts the adjectival inflection of the past participle down to its modifier function, but no similar analysis of the past participle with habban has been carried out so far.

In order to contribute to bridging this gap, this article deals with the participle in Old English and focuses on the loss of the adjectival segment of its inflection. More specifically, the aims of this research are (i) to quantify the instances of the explicit adjectival inflection of the past participle with habban in transitive constructions; (ii) to assess the progress of its deflexion; and (iii) to offer some paths of explanation for the pervicence of the adjectival segment of the inflection of the past participle with habban. The analysis is based on the York-Toronto-Helsinki Parsed Corpus of Old English Prose (Taylor et al., 2003; hereafter YCOE). ${ }^{1}$

The article is structured as follows. Section 2 reviews previous findings in the area of the past participle with bèon and habban. Section 3 presents the evidence for the inflected past participle with habban. The method is unfolded in Section 4. Section 5 discusses the results of the analysis of the adjectival inflection of the past participle with habban by text genre, period, dialect, and author. Section 6 considers the question at stake from the perspective of constituent order. To round off, Section 7 draws the main conclusions of the work, which insist on the co-relation between inflection and constituent order.

\section{REVIEW}

This section reviews previous findings in the area of the past participle and the verbs beon and habban. In general, more attention has been drawn by the copulative verb, in particular with respect to the grammaticalisation of the passive.

The main mechanisms of grammaticalisation are reanalysis and analogy (Hopper \& Traugott 2003). According to Brinton and Traugott (2005: 7), there are three types of reanalysis: change in constituency (syntactic or morphological bracketing), change in category labels (as in main verb > auxiliary) and boundary loss (as in going to > gonna). Thus described, the adjectival past participle with habban grammaticalises as the Presentday English perfect, while the adjectival participle with been is grammaticalised as the syntactic passive. This grammaticalisation represents the ultimate stage of an evolution from the morphologically adjectival Proto-Germanic participle. In this respect, Los (2015: 82) notes that the passive "may well be the earliest of the verbal periphrases in Germanic". 
For some authors, the adjectival construction consisting of bèon 'to be' and the past participle is reanalysed, at least partially, in Old English (Traugott, 1992; Denison, 1993). Other authors hold that this construction is not grammaticalised in Old English (Petré \& Cuyckens, 2008, 2009) or even that it remains fully analysable in this period (Jones \& MacLeod, 2018). The following arguments have been put forward in favour of the grammaticalisation of the passive construction: the existence of explicit agreement between the subject and the past participle (Traugott, 1992: 192), the expression of syntactic agents (Denison, 1993: 423), the development of the have-perfect (Toyota, 2008: 43) and the avoidance of coordination between adjectives and passive participles in the same copulative construction (Petré, 2014: 122).

As regards the adjectival inflection of the past participle in Old English, Kilpiö (2007: $329)$ gives the following figures: $11.6 \%$ of inflected participles in the texts written between 850-950 and 5.9\% in 950-1050. Wojtyś (2009) dates the loss of the adjectival inflection to the Middle English period (13th century).

On the specific construction of habban in combination with the past participle of the lexical verb, Traugott (1992: 192) states that habban and the participle appear "to have been reanalysed as a verbal complex" by Old English. Denison (1993: 414) concurs that "it might be possible to correlate lack of agreement in participles with a possible reanalysis from copula BE + participial adjective to auxiliary BE + lexical verb." Denison (1993: 341) also describes the necessary changes to constituent order (continuity of the verbal phrase) and to inflection (invariable past participle). Łęcki (2010: 169) points out that "OE HABBAN + past participle structure (...) functioned as a well-developed perfect already in the Old English period' and gives several arguments in favour of the completion of this process: the subject of habban becomes an agent and can be inanimate or abstract; habban can be used impersonally, ellipted and negated, in negative formations semantically incompatible with a resultative reading of habban. Turning to analogy, Łęcki (2010: 151-152) notes that "with neuter singular, non-accusative, clausal object or when the object is absent, past participles did not take adjectival inflections (...) The absence of overt marking (...) has been seen as an analogical factor that contributed to the eventual loss of inflected participles in English". Finally, Ringe and Taylor (2014: 437) agree that Old English has a periphrastic perfect with the auxiliary habban and the past participle.

With respect to the question of the deflexion of the participle, this term refers to "the loss of inflectional categories, not necessarily to the loss of all inflections" (Norde, 2001: 240). Allen (2003: 3) stresses the importance of deflexion in Early Middle English, usually known as the period of the levelling of inflections. Ogura (2009), in the same line, points out that, due to their phonemic resemblance, the endings -ende and-enne became interchangeable in late Old English. Martín Arista and Ojanguren López (2018a) relate the inflection of the participle in Old English to its syntactic function, in such a way that 
adjectival participles are inflected as adjectives more frequently than verbal participles. As regards habban and the past participle, Lęcki (2010: 150) remarks that "a majority of scholars endorse the view that English perfect has its origin in the structure containing HABBAN, past participle of transitive verb functioning as an adjective and object (...) The participle accompanying HABBAN originally assumed an adjectival inflection, in conformity with the object it modified." Mitchell (1985: 283) states that it is less consistent than bèon in taking an inflected participle, but he does not offer any quantitative data.

While concurring with the arguments in favour of the existence of a perfective construction with habban in Old English, I would like to finish this section by pointing out some facts that suggest that the process has not been fully completed yet in this period. This point has already been made by Kilpiö (2007: 341), who doubts that the process is complete in Old English, given that "at the end of this period there are still layered instances of the earlier type of construction that formed the starting point for the development." These layered instances may include, on the structural side, the fluctuation in the order of constituents, which may display, according to Mitchell (1985: 283), "all possible arrangements of the three elements concerned"; and, on the functional side, the lack of habban as a perfect auxiliary of habban itself (acknowledged by Lęcki, 2010: 171), the variation in the auxiliarisation of motion verbs between bēon and habban (Ogura 2018: 2), and the existence in Old English of only one example of passive of the type Ic habbe on fulluhte beon gefullod ' $\mathrm{I}$ have been baptised in the true faith' (cowsgosp,Lk_[WSCp]:12.50.4721). ${ }^{3}$ With this state of play, it may be helpful to provide additional criteria for assessing the progress of this process of grammaticalisation, including the comparison with been and the relation between inflection and constituent order.

\section{DATA AND SOURCES}

This study is based on the textual evidence available from the YCOE, which comprises 1.5 million words, annotated for part of speech and parsed for syntax.

The witnesses to the adjectival inflection of the past participle with the verb habban are listed and described in the Appendix. They can be classified, in terms of textual genre and, when relevant, author/translator into seven categories: Alfredian translations; The Bible; Gospels and Apocrypha; Other translations from Latin; Legal prose; Religious prose; Historical prose; and Ælfrician prose. Diachronic and dialectal aspects are also taken into account when available.

From the chronological point of view, evidence for the adjectival inflection of the past participle with habban has been found in early, classical and late texts, although most of them correspond to the 11th century. The earliest texts (9th century), according to the YCOE dating system, include Cura Pastoralis, Laws of Alfred, Alfred's Introduction to Laws, Charters and Wills and Anglo-Saxon Chronicle A. Vercelli Homilies, Boethius, Consolation 
of Philosophy, Bald's Leechbook, while Orosius can be dated to the 10th century. Laws of Athelred, Martyrology, Blickling Homilies, AElfric's Homilies Supplemental, and AElfric's Catholic Homilies (I and II) are dated by the YCOE to the turn of the 11th century. To the 11th century belong Bede's Ecclesiastical History, Laws of Cnut, Laws of Athelred (V and VI), Northumbra Preosta Lagu, Anglo-Saxon Chronicle C, Anglo-Saxon Chronicle D, Alfric's Lives of Saints, The Seven Sleepers, Martyrology, Vercelli Homilies, Heptateuch, West-Saxon Gospels, Gospel of Nichodemus (partly), Chrodegang of Metz, Gregory's Dialogues, Apollonius of Tyre, and Herbarium. Vindicta Salvatoris, Gerefa and the Laws of Ine are dated by the YCOE to the transition from the 11th to the 12th century. Finally, the Laws of William, Anglo-Saxon Chronicle E (Peterborough Chronicle), Gospel of Nichodemus (partly) and St. Augustine's Soliloquies belong in the 12th century.

From the dialectal point of view, the prose texts in which adjectivally inflected past participles with habban have been found are written in the West Saxon dialect, according to the information provided by the YCOE, except Charters and Wills (Anglian Mercian/Kentish/West Saxon), Martyrology (West Saxon/Anglian Mercian), Blickling Homilies (West Saxon/Anglian), Bede's Ecclesiastical History (West Saxon/Anglian Mercian), Gregory's Dialogues (West Saxon/Anglian Mercian), Herbarium (West Saxon/Anglian), and Bald's Leechbook (West Saxon/Anglian).

\section{METHOD}

Three main searches have been launched in the YCOE to carry out this analysis of habban and the past participle. The poetry segment of the York corpora has not been considered because structural aspects like adjacency and absolute order may be unpredictable in poetry for stylistic or metrical reasons.

Firstly, the YCOE has been searched for all the instances of habban and past participle. Example (1) presents the query, which has turned out a total of 1570 instances.

$$
\begin{aligned}
& \text { node: IP* } \\
& \text { query: }\left(\mathrm{IP}^{*} \text { idoms } * \mathrm{HVI}|* \mathrm{HVP} *| * \mathrm{HVD}^{*}\right) \\
& \text { AND }\left(\mathrm{IP}^{*} \text { idoms } * \mathrm{BEN} *|* \mathrm{HVN} *| * \mathrm{AXN}^{*} \mid * \mathrm{VBN}^{*}\right)
\end{aligned}
$$

Example (2) illustrates the phenomenon under analysis. The finite verb habban 'to have', the accusative NP pas word 'that word' and the past participle gesprecen 'said' are directly dominated by the node IP.

(2) Đa ða Drihten hafde pas word gesprecen. Pa wearð he genumen to heofonum (cocathom1,+ACHom_I,_21:348.105.4188) 'When the Lord had said this word, he was taken to heaven.' 


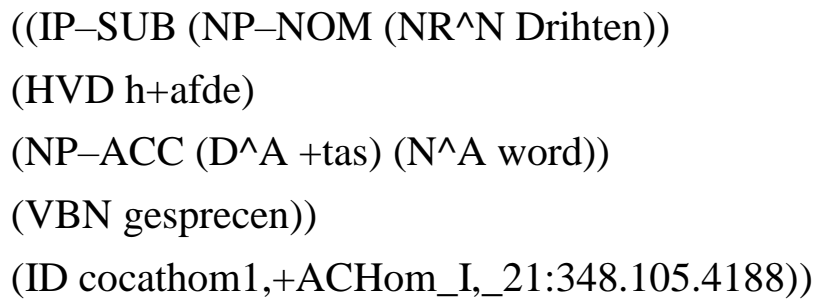

Secondly, all inflected past participles have been obtained with the query shown in example (3). A total of 136 inflected past participles with habban have been found. The figure of participles in the texts in which there are inflected past participles with habban rises to 1410 .

$$
\begin{aligned}
& \text { node: IP* } \\
& \text { query: (IP* idoms NP-ACC|NP-ACC-|NP-ACC-RSP|NP-ACC- } \\
& \text { RSP-|NP-ACC-RFL|NP-ACC-RFL-|NP-DAT|NP-DAT-|NP-DAT- } \\
& \text { RSP|NP-DAT-RSP-|NP-DAT-RFL|NP-DAT-RFL-|NP-GEN|NP- } \\
& \text { GEN-|NP-GEN-RSP|NP-GEN-RSP-|NP-GEN-RFL|NP-GEN- } \\
& \text { RFL-|NP|NP-|NP-RSP|NP-RSP-|NP-RFL|NP-RFL-) }
\end{aligned}
$$

Avoiding the nominative case, the query in (3) excludes the instances in which the zero inflectional ending may be mistaken for an uninflected past participle. As for the accusative, the YCOE tagging puts aside inflectionally unmarked past participles, which are tagged as $\mathrm{VBN}$ rather than as $\mathrm{VBN}^{\wedge} \mathrm{A}$.

Example (4) shows an instance of the finite verb habban together with a past participle with adjectival inflection (beswicenne 'eluded') that agrees in case, number and gender with the pronoun in the accusative noun phrase ( $b e$ 'you').

(4) Pu cwist ðat we habban pe beswicenne (coboeth,Bo:7.19.16.314) 'You say that we have eluded you' ((IP-SUB-SPE (NP-NOM (PRO^N we))

(HVPS h+abban)

(NP $(\mathrm{PRO}+\mathrm{te}))$

$\left(\mathrm{VBN}^{\wedge} \mathrm{A}\right.$ beswicenne)

(ID coboeth,Bo:7.19.16.314))

Approximately, ten percent of the past participles are inflected not only as non-finite forms of the verb $(-e d /-o d /-e n)$ but also as adjectives (with the strong or weak adjectival inflection). Additional searches are launched in these results so as to take further steps of 
analysis, including the absolute position of the past participle with habban (non-final vs. final) and its relative position (adjacent to the object).

Thirdly, the results are compared with those evinced by beon and the past participle. Example (5) shows the relevant nodes and the query.

$$
\begin{aligned}
& \text { node: IP*|PTP* } \\
& \text { query: ((IP* idoms BED*|BEP*) } \\
& \text { AND (IP* idoms } \left.\left.* \mathrm{VBN}^{\wedge} *\left|* \mathrm{HVN}^{\wedge} *\right| * \mathrm{BEN}^{\wedge *}\right)\right) \\
& \text { OR }\left(\mathrm{PTP}^{*} \text { idoms } * \mathrm{VBN}^{\wedge} *\left|* \mathrm{HVN}^{\wedge} *\right| * \mathrm{BEN}^{\wedge *}\right)
\end{aligned}
$$

As can be seen in (6), the nominative noun phrase (ealle ping 'all things') agrees in plural number with the finite verb (syndon 'are'). It also agrees in case, number and gender with the past participle (gesceapene 'shaped').

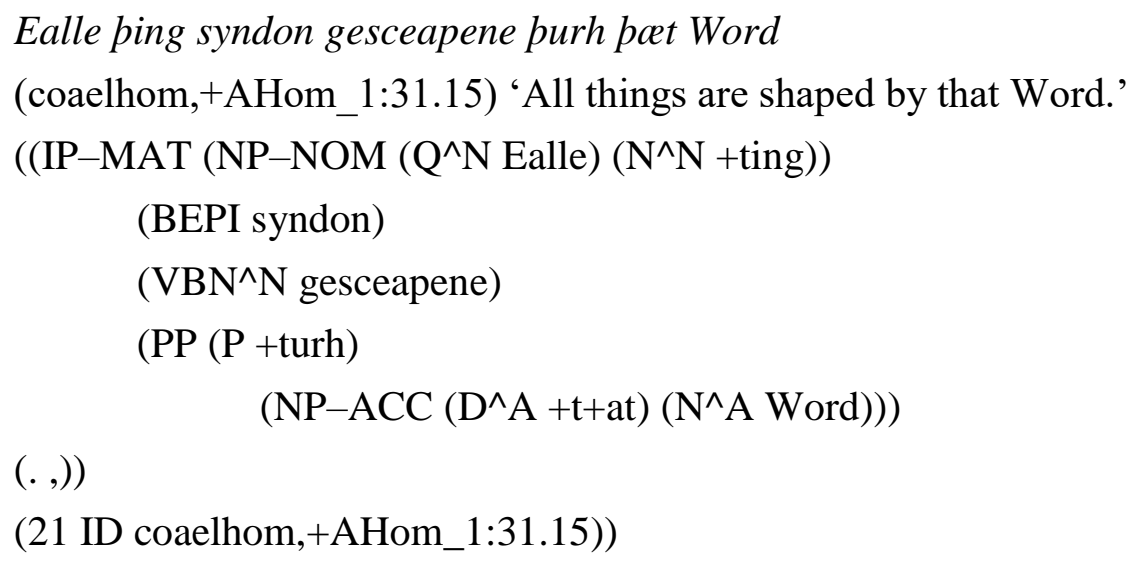

In spite of the structural similarities that arise between the instances in (4) and (6), the past participle is far more frequent with beon than with habban, and gets adjectival inflectional morphemes more frequently. The number of past participles with bèon in the texts in which there are past participles with habban is in the area of eighteen thousand, approximately one third of which are inflected as adjectives. This figure plunges to less than ten percent in the participles with habban. These aspects are discussed in more detail in the following section.

\section{RESULTS}

This section discusses the data found in the text groups presented in Section 3 (see also Appendix).

Beginning with the group of Alfredian translations, the mean of adjectivally inflected past participles with habban is around ten percent. Interestingly, the mean of this group is very similar to the one of the corpus of analysis (9.6 percent). Boethius evinces a percentage 
of inflection slightly under the mean, while Bede is over. Gregory's Dialogues and Orosius show rates of inflection clearly below average, around five percent. The comparison with bèon is relevant in relative terms and, above all, in absolute terms. In relative terms, the mean of adjectivally inflected past participles with bèon is almost three times the one of habban. In absolute terms, the figure of past participles with bèon (both uninflected and inflected) is ten times as much as the corresponding figure with habban. These figures are tabulated in Table1.

\begin{tabular}{lllllll}
\hline & \multicolumn{2}{l}{ PtPp with $\boldsymbol{b e}$ en } & \multicolumn{3}{l}{ PtPp with habban } \\
\hline $\begin{array}{l}\text { Alfredian } \\
\text { translations }\end{array}$ & Inflected & Total & $\%$ & Inflected & Total & $\%$ \\
\hline cobede & 399 & 1645 & 24.2 & 6 & 46 & 13 \\
\hline coboeth & 89 & 301 & 29.5 & 18 & 181 & 9.9 \\
\hline cocura & 307 & 1114 & 27.5 & 19 & 105 & 18 \\
\hline coorosiu & 120 & 650 & 18.4 & 7 & 148 & 4.7 \\
\hline cosolilo & 9 & 49 & 18.3 & 8 & 44 & 18.1 \\
\hline cogregd & 692 & 2188 & 31.6 & 4 & 69 & 5.7 \\
\hline Total & 1616 & 5947 & 27.1 & 62 & 593 & 10.4 \\
\hline
\end{tabular}

Table 1. Adjectival inflection of the past participle in Alfredian translations.

The translations throw rates of adjectival inflection of the participle in the area of ten percent. The group of Other Latin translations is over the mean, whereas The Bible, Gospels and Apocrypha is under the mean. In the latter group, the rates of adjectival inflection are very low in The Gospel of Nichodemus (3.4 percent) and in the Heptateuch (4.9 percent). While Vindicta Salvatoris is above the mean, the West Saxon Gospels triplicate the mean, but this rate has to be taken with caution because the absolute figures are very low. It is worth commenting, with respect to this group, that the four texts evince similar rates of inflection of the past participle with bèon. On the side of habban, although the texts with absolute figures under fifty occurrences were put aside, the rates would range between 3.4 and 8.6 percent. The total number of past participles with habban is approximately one tenth of the participles with bēon, a proportion similar to the one holding in Alfredian translations. These figures are summarised in Table 2.

\begin{tabular}{lllllll}
\hline & \multicolumn{3}{l}{ PtPp with $\boldsymbol{b} \overline{\boldsymbol{e}} \boldsymbol{l}$ P } & \multicolumn{4}{l}{ PtPp with habban } \\
\hline $\begin{array}{l}\text { The Bible, Gospels, } \\
\text { and Apocrypha }\end{array}$ & Inflected & Total & $\%$ & Inflected & Total & $\%$ \\
\hline cootest & 186 & 538 & 34.5 & 3 & 61 & 4.9 \\
\hline cowsgosp & 328 & 1059 & 30.9 & 6 & 18 & 33.3 \\
\hline conicod & 68 & 205 & 33.1 & 2 & 58 & 3.4 \\
\hline
\end{tabular}




\begin{tabular}{lllllll}
\hline covinsal & 17 & 46 & 36.9 & 2 & 14 & 14.2 \\
\hline Total & 599 & 1848 & 32.4 & 13 & 151 & 8.6 \\
\hline
\end{tabular}

Table 2. Adjectival inflection of the past participle in The Bible, Gospels and Apocrypha.

The absolute figures of the group of Other Latin translations are very low for habban and must be taken with caution. As is tabulated in Table 3, there is a wide gap between the occurrences of the past participle with the two verbs. As in the groups described so far, the ratio habban: bēon is approximately 1: 10 on average, but the difference is even bigger in texts like Bald's Leechbook, whose rate of adjectival inflection of the past participle with been is over sixty percent. This rate is completely unrivaled in the context of the results of this study.

\begin{tabular}{lllllll}
\hline & \multicolumn{2}{l}{ PtPp with $\boldsymbol{b} \overline{\boldsymbol{e}} \boldsymbol{l}$} & \multicolumn{3}{l}{ PtPp with habban } \\
\hline $\begin{array}{l}\text { Other Latin } \\
\text { translations }\end{array}$ & Inflected & Total & $\%$ & Inflected & Total & $\%$ \\
\hline cochdrul & 80 & 202 & 39.6 & 1 & 20 & 5 \\
\hline coherbar & 214 & 468 & 31.6 & 3 & 7 & 42.8 \\
\hline colaece & 222 & 362 & 61.3 & 1 & 5 & 20 \\
\hline coapollo & 21 & 89 & 23.5 & 1 & 17 & 0.5 \\
\hline Total & 537 & 1121 & 47.9 & 6 & 49 & 12.2 \\
\hline
\end{tabular}

Table 3. Adjectival inflection of the past participle in Other Latin translations.

The group of Legal prose has the lowest rate of adjectival inflection of the past participle in the textual selection. The absolute figures are not very high, neither for habban nor for bēon. The details can be seen in Table 4.

\begin{tabular}{lllllll}
\hline \multicolumn{4}{l}{ PtPp with $\boldsymbol{b} \overline{\mathbf{e}} \boldsymbol{l}$} \\
$\begin{array}{l}\text { Legal } \\
\text { prose }\end{array}$ & Inflected & Total & $\%$ & Inflected & Total & $\%$ \\
\hline colaw & 13 & 90 & 14.4 & 1 & 39 & 2.5 \\
\hline codocu & 14 & 55 & 25.4 & 1 & 25 & 4 \\
\hline Total & 27 & 145 & 18.6 & 2 & 64 & 3.1 \\
\hline
\end{tabular}

Table 4. Adjectival inflection of the past participle in Legal prose.

As is the case with Legal prose, there is not much evidence for the inflected past participle in Religious prose. Even the figure of past participles with bēon is low if compared with the results of this verb. At the same time, Religious prose evinces the highest rate of adjectival inflection of the past participle with habban, as can be seen in Table 5.

\begin{tabular}{|c|c|c|c|c|c|}
\hline & PtPp with bēon & & PtPp wit & abban & \\
\hline Religious & Inflected & $\%$ & Inflected & Total & $\%$ \\
\hline
\end{tabular}

(C) Servicio de Publicaciones. Universidad de Murcia. All rights reserved. IJES, vol. 20(1), 2020, pp. 51-71 


\begin{tabular}{lllllll}
\hline prose & & & & & & \\
\hline comart & 72 & 468 & 15.3 & 1 & 11 & 9.1 \\
\hline coblick & 149 & 536 & 27.7 & 7 & 43 & 16.2 \\
\hline coverhom & 226 & 679 & 33.2 & 9 & 61 & 14.7 \\
\hline cowulf & 82 & 245 & 33.4 & 6 & 31 & 19.3 \\
\hline Total & 529 & 1928 & 27.4 & 23 & 146 & 15.7 \\
\hline
\end{tabular}

Table 5. Adjectival inflection of the past participle in Religious prose.

A similar problem arises with respect to Historical prose, as is tabulated in Table 6 . Nevertheless, there is a decrease in the adjectival inflection of the past participle if the A and the E part of The Anglo-Saxon Chronicle are compared. This is in accordance with the datation of these texts (9th. vs. 12th century); with the total data of the analysis presented in this work, which shows a decrease between two reliable groups of texts such as Alfredian translations (9th century) and Ælfrician prose (10-11th century); and with the parallel evolution of the past participle with beon, which clearly decreases between the A and the $\mathrm{E}$ texts of The Anglo-Saxon Chronicle.

\begin{tabular}{lllllll}
\hline \multicolumn{3}{l}{ PtPp with $\boldsymbol{b e}$ en } & \multicolumn{5}{l}{ PtPp with habban } \\
\hline $\begin{array}{l}\text { Historical } \\
\text { prose }\end{array}$ & Inflected & Total & $\%$ & Inflected & Total & $\%$ \\
\hline cochronA & 37 & 170 & 21.7 & 4 & 31 & 12.9 \\
\hline cochronC & 39 & 244 & 15.9 & 6 & 44 & 16.6 \\
\hline cochronD & 52 & 291 & 17.8 & 5 & 54 & 9.2 \\
\hline cochronE & 77 & 461 & 16.7 & 6 & 55 & 10.9 \\
\hline Total & 205 & 1166 & 17.5 & 21 & 184 & 11.4 \\
\hline
\end{tabular}

Table 6. Adjectival inflection of the past participle in Historical prose.

Elfrician prose is the most consistent group and, as such, the most reliable when it comes to interpreting the data. This group is restricted to one textual genre, one idiolect, one dialect and a well-defined time span. Furthermore, the word count of the four texts together is well over 275,000 words, around one sixth of the YCOE. For qualitative and quantitative reasons, then, this segment of the data is remarkably representative of the written records of Old English as a whole. Leaving aside Legal prose, Ælfrician prose evinces the lowest rate of adjectival inflection of the past participle with habban. It seems that Ælfric the grammarian (or the purist) prefers the adjectivally inflected past participle in the passive construction with bèon and the adjectivally uninflected past participle in the transitive construction with habban. This is rather unexpected, considering that other religious works clearly favour the adjectivally past participle with habban. Indeed, the Blickling Homilies, the Vercelli Homilies and the Homilies of Wulfstan quadruplicate or even quintuplicate the rate of inflection found in Ælfric. Ælfric and Wulfstan are practically coetaneous and, while the former inflects as 
adjectives four past participles in one hundred, the latter declines as adjectives nearly twenty percent of the past participles. Although more research is needed in this area, this difference could be attributed to Wulfstan's preference for formulae and repetitions, which, according to Beechy (2010: 61), define his homyletic style. Focusing on habban, there is a remarkable reduction in the rate of the inflected past participle between Alfredian translations (around ten percent) and Ælfrician prose (four percent). The figures for the latter are presented in Table 7.

\begin{tabular}{lllllll}
\hline & PtPp with bēon & \multicolumn{5}{l}{ PtPp with habban } \\
\hline $\begin{array}{l}\text { Elfrician } \\
\text { prose }\end{array}$ & Inflected & Total & $\%$ & Inflected & Total & $\%$ \\
\hline coaelhom & 271 & 700 & 38.7 & 1 & 31 & 3.22 \\
\hline cocathom & 1138 & 3219 & 35.3 & 5 & 106 & 4.71 \\
\hline coaelive & 541 & 1431 & 37.8 & 2 & 67 & 2.9 \\
\hline cosevensl & 41 & 78 & 52.5 & 1 & 19 & 5.2 \\
\hline Total & 1991 & 5428 & 36.6 & 9 & 223 & 4 \\
\hline
\end{tabular}

Table 7. Adjectival inflection of the past participle in Ælfrician prose.

As can be seen in Table 8, early texts show higher rates of adjectival inflection of the past participle with habban. For instance, the Cura Pastoralis (9th century) presents a rate of eighteen percent while AElfric's Catholic Homilies (11th century) is under five percent. The same can be said with respect to The Anglo-Saxon Chronicle. Part A of The Anglo-Saxon Chronicle (9th century) evinces a rate of inflection of the past participle with habban of 12.9 percent whereas Part D (11th century) has a rate of 9.2 percent. These remarks may represent trends rather than well defined lines of evolution, though.

\begin{tabular}{lllllll}
\hline & PtPp with $\boldsymbol{b} \bar{e}$ on & \multicolumn{4}{l}{ PtPp with habban } \\
\hline Summary & Inflected & Total & $\%$ & Inflected & Total & $\%$ \\
\hline $\begin{array}{l}\text { Alfredian } \\
\text { translations }\end{array}$ & 1616 & 5947 & 27.1 & 62 & 593 & 10.4 \\
\hline $\begin{array}{l}\text { The Bible, } \\
\text { Gospels }\end{array}$ & 599 & 1848 & 32.4 & 13 & 151 & 8.6 \\
\hline $\begin{array}{l}\text { Other Latin } \\
\text { translations }\end{array}$ & 537 & 1121 & 47.9 & 6 & 49 & 12.2 \\
\hline Legal prose & 27 & 145 & 18.6 & 2 & 64 & 3.1 \\
\hline $\begin{array}{l}\text { Religious } \\
\text { prose }\end{array}$ & 529 & 1928 & 27.4 & 23 & 146 & 15.7 \\
\hline $\begin{array}{l}\text { Historical } \\
\text { prose }\end{array}$ & 205 & 1166 & 17.5 & 21 & 184 & 11.4 \\
\hline $\begin{array}{l}\text { Elfrician } \\
\text { prose }\end{array}$ & 1991 & 5428 & 36.6 & 9 & 223 & 4 \\
\hline
\end{tabular}

(C) Servicio de Publicaciones. Universidad de Murcia. All rights reserved. IJES, vol. 20(1), 2020, pp. 51-71 


\begin{tabular}{lcccccc}
\hline Total & 5504 & 17583 & 31.3 & 136 & 1410 & 9.6 \\
\hline \multicolumn{5}{c}{ Table 8. Adjectival inflection of the past participle by text type. }
\end{tabular}

With the exception of the West Saxon Gospels, which shows the same rate of inflection of the past participle with bēon and with habban, the rest of the texts in the YCOE selection diverge in this respect. This divergence can be assessed in terms of the ratio habban : béon. The maximal divergence corresponds to Ælfrician prose (ratio habban : bēon $=0.1$ ) and Legal prose (0.16). The translations from Latin diverge moderately. The ratio habban : bēon is 0.38 in Alfredian translations, 0.26 in The Bible, Gospels and Apocrypha, and 0.25 in Other translations. Two groups of vernacular prose show the minimal divergence as to the inflection with habban and bēon: Historical prose (0.65) and Religious prose (0.57). The divergences just noted can be the result of the high absolute figure of past participles with bèon, as is the case with Alfredian prose and Ælfrician prose; or a consequence of the low absolute number of participles with habban, as happens to Legal prose and Other Latin translations.

All in all, two main categories of texts can be distinguished: translations from Latin and vernacular prose. While the groups comprising translations from Latin are homogeneous and present rates of adjectival inflection with habban not far from the mean (the range is 8.6-12.2 percent, and the mean 9.6 percent), the groups of vernacular prose are divergent in that they show the lowest and the highest rates of adjectival inflection. The group of Legal prose has 3.1 percent and Ælfrician prose has 4 percent. On the other hand, Historical prose presents a rate of adjectival inflection of 11.4 percent and Religious prose evinces the highest rate, 15.7 percent (approximately five percent above the mean).

These convergences, however, are not enough to explain the inflection of the past participle with habban either on a dialectal or on a diachronic basis. In the following section, the phenomenon under scrutiny is discussed from the angle of constituent order.

\section{DISCUSSION}

Given that the past participle with habban plays a necessarily verbal role, the paths of explanation for the evidence presented so far are sought in the syntax of the language. The point of departure of this explanation is the structural reanalysis that, according to Denison (1993: 341), has led to the Present-day English perfect: "from a sentence brace in main clauses, with non-adjacency of finite HAVE and non-finite V, and accusative adjectival inflection on V; to adjacency of HAVE and V and no adjectival inflection on V." The completion of this pattern of reanalysis may indicate that the grammaticalisation of the perfect is over, notwithstanding the semantic differences between the Old English and the Present-day English construction, which are underlined by Denison (1993: 352) and Ringe $\&$ Taylor (2014: 437). As is shown below, the analysis of the relative order of the finite verb 
and the past participle, when applied to bèon, turns out similar results, which reinforces the explanatory character of adjacency.

In the remainder of this section, constituent order is considered with respect to relative position (the adjacency of the past participle and the accusative noun phrase that complements habban) and absolute position (the past participle in the final position of the clause, which is aligned as a braced construction that displays, in this order, the finite verb, the accusative noun phrase and the past participle).

731 uninflected past participles with habban appear in non-adjacent constructions, whereas 410 can be found in adjacent constructions NP-PtPp or PtPp-NP. In percentual terms, adjacent participles represent thirty-six percent of uninflected past participles, nonadjacent being sixty-four percent of uninflected participles. The main patterns of constituent order in which adjacent uninflected past participles appear are: firstly, the past participle preceding the finite form of the verb in the final position of a dependent clause (230 instances), as is the case with asaed haefde in Đa se Wisdom ða pis spell asced hafde, pa ongon he singan (coboeth,Bo:40.141.9.2817) 'After Wisdom had made this speech, he started singing'; secondly, the brace HABBAN-NP-PtPp in main clauses (fifty-seven instances), such as He hafde anne licðrowere belocen on anum clyfan (coaelive,+ALS_[Basil]:480.795) 'They had locked a leper in a cubiculum'; thirdly, the completely modern order HABBAN-PtPp-NP (fifty-one instances), as can be seen in Ac heo hafde gecoren Crist hyre to brydguman (coaelive,+ALS_[Eugenia]:349.401) 'But she had chosen Christ for her as bridegroom'; and fourthly, the brace HABBAN-NP-PtPp in dependent clauses (twenty-nine instances). The braced construction, both in main and dependent clauses, reaches a total of eighty-six instances, which represents twenty-one percent of non-adjacent uninflected past participles with habban.

Out of the 136 past participles with habban that show adjectival inflection (see Table 8), eighty are adjacent to the accusative noun phrase, either in NP-PtPp or PtPp-NP order. This is the case, for instance, with hine gereahtne in Gif cenegu gesceaft tiohhode pat hio wið his willan sceolde winnan, hwoet hio meahte wið swa mihtigne swa we hine gereahtne habbað? (coboeth,Bo:35.98.13.1897) 'If any creature thought that she should fight against his will, what might she do against such a mighty one as we have described him?'; and me gedonne in Bearnleasne ge habbað me gedonne (cootest,Gen:42.36.1793) 'You have made me heirless'. Adjacent inflected past participles are mainly found in braced constructions (HABBAN-NP-PtPp), either in main clauses (thirty-six instances) or in dependent clauses (twenty-three instances). For example, $P u$ hafst me nu manega bysna gereihte (cosolilo,Solil_3:66.26.926) 'You have set many examples for me' is a braced construction in a main clause; while $P u$ cwist ðat we habban pe beswicenne (coboeth,Bo:7.19.16.314) 'You say that we have deceived you' illustrates the brace in dependent clauses. Braced constructions constitute two thirds of the occurrences of the adjacent inflected past participle. 
The other frequent structural pattern in which adjacent inflected past participles occur is the dependent clause with final finite verb (NP-PtPp-HABBAN), of which there are twentythree instances, such as \& hie alle on pone Cyning warun feohtende op pat hie hine ofslaegene haefdon (cochronA-CC,ChronA_[Plummer]:755.16.522) 'And they all would fight against the king, until they killed him'. The remaining forty-seven inflected past participles are non-adjacent, including In patientia uestra possidebitis animas uestras; pat is on engliscre sprace, On eowrum geðylde ge habbað eowre sawla soðlice gehealdene (coaelive,+ALS_[Memory_of_Saints]:334.3509) 'In patientia uestra possidebitis animas uestras, which is in the English language in your patience you have certainly held your souls.', and Pin agen geleafa pe haefp gehaledne (coblick,HomS_8_[BlHom_2]:15.24.201) 'You have kept your own belief.' Overall, 65.4 percent of inflected past participles occur in adjacent constructions, with the corresponding 34.6 percent qualifying as non-adjacent to the accusative noun phrase.

The figures of inflected past participles can be described as the complete reversal of the ones of uninflected past participles. One the one hand, if the accusative noun phrase and the past participle are adjacent, two thirds of the verbal forms are inflected. On the other hand, if there is no adjacency between the accusative noun phrase and the past participle, two thirds of the verbal forms are uninflected: there is a total of 499 adjacent past participles with habban, and 778 non-adjacent ones. Of the adjacent past participles, eighty-nine are inflected (21.7 percent) and 489 uninflected. Out of the total of 778 non-adjacent past participles, forty-seven display adjectival inflection (6.4 percent), whereas 731 qualify as uninflected. In sum, the rate of inflection of adjacent past participles nearly triplicates the rate of non-adjacent past participles.

The picture that emerges is twofold. While the low rate of inflection of the past participle indicates that the reanalysis into the Present-day perfect is nearly complete, the co-occurrence of the inflection of the non-finite form with its final position evidences that the total loss of inflection requires the rigidification of constituent order, with the past participle following the finite form of the verb and preceding the noun phrase.

Interestingly, the loss of the inflection in the construction involving bēon and the past participle evinces similar rates. It has to be borne in mind that the adjacency of the intransitive construction is restricted to the two verbal forms, whereas the transitive construction with habban displays two verbs and an accusative noun phrase. Mutatis mutandis, it turns out that approximately three fourths of the adjacent constructions bēonPtPp/PtPp-bèon do not mark the adjectival inflection of the past participle, with the corresponding one fourth of inflected adjacent constructions. This can be seen in Table 9.

\begin{tabular}{ll}
\hline PtPp with bēon & \\
\hline uninflected & inflected \\
\hline
\end{tabular}




\begin{tabular}{llll}
\hline $\begin{array}{l}\text { Adjacency bēon- } \\
\text { PtPp }\end{array}$ & $\begin{array}{l}\text { Adjacency PtPp- } \\
\text { bēon }\end{array}$ & $\begin{array}{l}\text { Adjacency bēon- } \\
\text { PtPp }\end{array}$ & $\begin{array}{l}\text { Adjacency PtPp- } \\
\text { bēon }\end{array}$ \\
\hline 4698 & 2424 & 1499 & 829 \\
\hline total & $7122(75.3 \%)$ & total & $2328(24.6 \%)$ \\
\hline Grand total & 9450 & & \\
\hline \multicolumn{4}{r}{ Table 9. The past participle with bēon in the YCOE. }
\end{tabular}

Three aspects deserve some attention if this reasoning is correct. Firstly, the order of constituents of the passive with bèon may also be explanatory, along with the function, as to the deflexion of the past participle. Secondly, the rate of deflexion of the past participle in adjacent configurations illustrates the faster pace of the reanalysis of habban with respect to been, although the difference is not wide. Thirdly, this work has not furnished enough evidence or arguments so as to make a claim of direct causal relation between order of constituents and deflexion. To a certain extent, I agree with Kilpiö's (2007: 341) remark that "loss of inflection and changes in word-order are not directly causally linked in the sense that one would trigger the other. They rather seem to be events that work towards the same goal, but not at the same pace". However, the parallelism between the past participle with beon and habban probably indicates that the relative position and the adjectival marking of the past participle are not fully independent from each other.

\section{CONCLUSSION}

This article has analysed the partial deflection of the past participle with habban on the grounds of data retrieved from the YCOE. The results have been presented by text and the explanation has been sought in the comparison with bēon and constituent order. Three types of conclusions can be drawn from this research.

On the quantitative side, there is a strong correlation between (lack of) inflection and (lack of) adjacency. Around two thirds of the uninflected participles are non-adjacent, while two thirds of the inflected participles are adjacent. This correlation is also present in adjacent constructions with bēon, in which the ratio of inflected to uninflected past participles is $1: 4$.

On the qualitative side, this analysis has evidenced that a grammarian no less than Ælfric of Eynsham opts for the adjectivally inflected past participle in the passive construction with bēon but clearly dislikes the adjectivally inflected past participle in the transitive construction with habban. This might indicate a demise of the adjectival inflection of the past participle.

On the explanatory side, the convergence of some results of the analysis of been and habban underlines the relevance of constituent order for the assessment of the grammaticalisation of the constructions with the past participle and highlights the relation between inflection and order. The data indicate that the reanalysis the habban+past participle construction is nearly over. Not even adjacent past participles are regularly inflected. 
However, the low textual frequency of the construction points to regularisation, in the sense of automation, rather than to generalisation. It seems that a higher frequency of use is needed before grammaticalisation is complete, but more research is needed in this area.

\section{ACKNOWLEDGEMENT}

This research has been funded through the grant FFI2017-83360-P, which is thankfully acknowledged.

\section{NOTES}

1. I would like to thank Susan Pintzuk for her help and guidance with the searches in the YCOE. Any errors or misconceptions remain entirely mine.

2. The YCOE was consulted in April 2018. The full inventory of tags used in the YCOE is available from http://wwwusers.york.ac.uk/ lang22/YCOE/doc/annotation/YcoeLite.htm\#syntactic_labels.

3. The example is not uncontroversial, though. Visser (1984: §2161; in Toyota, 2009: 209) thinks that it is Old English, but Mitchell (1985: §753; in Toyota, 2009: 209) considers it Middle English.

\section{REFERENCES}

Allen, C. (2003). Deflexion and the development of the genitive in English. English Language and Linguistics, 7(1), 1-28.

Bately, J. (1980). The Old English Orosius. London: Oxford University Press.

Beechy, T. (2010). The Poetics of Old English. Farnham: Ashgate Publishing Limited.

Bethurum, D. (1957). The Homilies of Wulfstan. Oxford: Clarendon Press.

Blake, N. (1964). The Phoenix. Manchester: Manchester University Press.

Brinton, L. \& Traugott, E. C. (2005). Lexicalization and Language Change. Cambridge: Cambridge University Press.

Campbell, J. (1959). The Advent lyrics of the Exeter Book. Princeton: Princeton University Press.

Carnicelli, T. (1969). King Alfred's version of St. Augustine's Soliloquies. Cambridge, MA: Harvard University Press.

Classen, E. \& Harmer, F. (1926). An Anglo-Saxon chronicle. Manchester: Manchester University Press.

Clemoes, P. (1997). Alfric's Catholic Homilies: The first series. Oxford: Oxford University Press.

Cockayne, O. (1864-1866). Leechdoms, wortcunning and starcraft of early England. Rolls Series 35, vol. 1. 70-324. London: Her Majesty's Stationery Office.

Crawford, S. (1922). The Old English version of the Heptateuch. Alfric's Treatise on the Old and New Testament and his Preface to Genesis. London: Oxford University Press.

Cross, J. (1996). Two Old English apocrypha and their manuscript source: The Gospel of Nichodemus and The Avenging of the Saviour, with contributions by Denis Brearley, Julia 
Crick, Thomas Hall \& Andy Orchard. Cambridge Studies in Anglo-Saxon England, 19, 139247.

de Vriend, H. (1984). The Old English Herbarium and Medicina de quadrupedibus. London: Oxford University Press.

Denison, D. (1993). English historical syntax: Verbal constructions. London: Longman.

Dobbie, E. (1953). Beowulf and Judith. The Anglo-Saxon poetic records, IV. New York, NY: Columbia University Press.

Endter, W. (1922). König Alfreds des Grossen Bearbeitung der Soliloquien des Augustinus. Darmstadt: Wissenschaftliche Buchgesellschaft.

Godden, M. (1979). Alfric's Catholic Homilies: The second series. London: Oxford University Press.

Goolden, P. (1958). The Old English Apollonius of Tyre. London: Oxford University Press.

Gradon, P. (1958). Cynewulf's Elene. London: Methuen.

Harmer, F. (1914). Select English historical documents of the ninth and tenth centuries. Cambridge: Cambridge University Press.

Healey, A. diPaolo. (Ed.). 2016. The Dictionary of Old English in electronic form A-H. Toronto: Dictionary of Old English Project, Centre for Medieval Studies, University of Toronto.

Hecht, H. 1965 (1900-1907). Bischof Warferth von Worcester Übersetzung der Dialoge Gregors des Grossen. Darmstadt: Wissenschaftliche Buchgesellschaft.

Herzfeld, G. (1973/1900). An Old English Martyrology. London: Trübner.

Hill, J. (1994). Old English minor heroic poems. Durham: Durham Medieval Texts.

Hopper, P. \& Traugott, E. C. (2003). Grammaticalization. Cambridge: Cambridge University Press.

Hulme, W. (1903-4). The Old English Gospel of Nicodemus. Modern Philology, 1, 610-14.

Jones, H. \& Macleod, M. (2018). The status of passive constructions in Old English. Transactions of the Philological Society, 116(1), 59-90.

Kilpiö, M. (2007). Auxiliation in progress: Diachronic grammaticalisation changes in Old English and Early Middle English HAVE perfects. In M. Rissanen, M. Hintikka, L. Kahlas-Tarkka \& R. McConchie (Eds.), Change in Meaning and the Meaning of Change: Studies in Semantics and Grammar from Old to Present-Day English (pp. 323-343). Helsinki: Société Néophilologique.

Kotzor, G. (1981). Das Alternglische Martyrologium, vol. II. München: Verlag der Bayerischen Akademie der Wissenschaften.

Krapp, G. (1906). Andreas and the Fates of the Apostles. Boston, MA: Ginn.

Krapp, G. (1932). The Vercelli Book. The Anglo-Saxon poetic records II. New York, NY: Columbia University Press.

Krapp, G. \& Dobbie, E. (1936). The Exeter Book. The Anglo-Saxon poetic records III. New York, NY: Columbia University Press.

Lamont, G. (2015). The present participle as a marker of style and authorship in Old English biblical translation. Unpublished Doctoral Dissertation, Centre for Medieval Studies, University of Toronto, Canada.

Łęcki, A. (2010). Grammaticalisation Paths of Have in English. Frankfurt am Main: Peter Lang.

Lieberman, F. (1903-16). Die Gesetze der Angelsachsen. Halle.

Los, B. (2015). A historical syntax of English. Edinburgh: Edinburgh University Press. 
Magennis, H. (1994). The Anonymous Old English Legend of the Seven Sleepers. Durham: Durham Medieval Texts.

Martín Arista, J. \& Ojanguren López, A. E. (2018a). The adjectival and verbal participle with bèon in Old English: A morpho-syntactic analysis. SELIM, 23, 27-53.

Martín Arista, J. \& Ojanguren López, A. E. (2018b). Grammaticalization and deflexion in progress. The past participle in the Old English passive. Studia Neophilologica, 90(2), 155-175.

Miller, T. (1959-1963/1890-1898). The Old English version of Bede's Ecclesiastical History of the English People. London: Oxford University Press.

Mitchell, B. (1985). Old English syntax. Concord, the parts of speech and the sentence, vol. 1. Oxford: Oxford University Press.

Morris, R. (1967/1880). The Blickling Homilies. London: Trübner.

Napier, A. (1971/1916). The Old English version, with the Latin original, of the Enlarged Rule of Chrodegang together with the Latin original. London: Kegan Paul.

Norde, M. (2001). Deflexion as a counterdirectional factor in grammatical change. Language Sciences, 23, 231-264.

Ogura, M. (2009). The interchangeability of the endings - ende and -enne in Old and Early Middle English. English Studies, 90(6), 721-734.

Ogura, M. (2018). Periphrases in Medieval English. Frankfurt am Main: Peter Lang.

Petré, P. (2014). Constructions and environments: Copular, passive, and related constructions in Old and Middle English. Oxford: Oxford University Press.

Petré, P. \& Cuyckens, H (2008). The Old English copula weorðan and its replacement in Middle English. In M. Gotti, M. Dossena \& R. Dury (Eds.), English historical linguistics 2006, vol 1 (pp. 23-48). Amsterdam: John Benjamins.

Petré, P. \& Cuyckens, H. (2009). Constructional change in Old and Middle English copular constructions and its impact on the lexicon. Folia Linguistica Historica, 30, 311-66.

Plummer, C. (1965/1899). Two of the Saxon chronicles parallel. Oxford: Clarendon Press.

Pope, J. (1968). Homilies of AElfric, a supplementary collection. London: Oxford University Press.

Ringe, D. \& Taylor, A. (2014). The Development of Old English. A Linguistic History of English, Volume II. Oxford: Oxford University Press.

Robertson, A. (1956/1939). Anglo-Saxon charters. Cambridge: Cambridge University Press.

Rositzke, H. (1940). The C-Text of the Old English chronicles. Bochum-Langendreer: H. Pöppinghaus.

Scragg, D. (1992). The Vercelli Homilies and related texts. Oxford: Oxford University Press.

Sedgefield, W. 1899. King Alfred's Old English version of Boethius de Consolatione Philosophiae. Oxford: Clarendon Press.

Skeat, W. (1871-1887). The Four Gospels in Anglo-Saxon, Northumbrian and Old Mercian versions. Cambridge: Cambridge University Press.

Skeat, W. (1966/1900). AElfric's Lives of Saints. London: Oxford University Press. Squires, A. (1988). The Old English Physiologus. Durham: Durham Medieval Texts.

Sweet, H. (1958/1871). King Alfred's West-Saxon version of Gregory's Pastoral Care. London: Oxford University Press.

(C) Servicio de Publicaciones. Universidad de Murcia. All rights reserved. IJES, vol. 20(1), 2020, pp. 51-71 Print ISSN: 1578-7044; Online ISSN: 1989-6131 
Taylor, A., Warner, A., Pintzuk, S. \& Beths, F. (Eds.). (2003). The York-Toronto-Helsinki parsed corpus of Old English prose. Department of Language and Linguistic Science, University of York.

Toyota, J. (2008). Diachronic change in the English passive. Basingstoke: Palgrave Macmillan.

Toyota, J. (2009). Passive as a tense-aspectual construction revisited: the case of Germanic languages. Groninger Arbeiten zur Germanistischen Linguistik, 49, 200-214.

Traugott, E. C. (1992). Syntax. In R. Hogg (Ed.), The Cambridge history of the English language, vol. 1 (pp.186-201). Cambridge: Cambridge University Press.

Whitelock, D. (1930). Anglo-Saxon wills. Cambridge: Cambridge University Press.

Williams, B. (1966). Gnomic poetry in Anglo-Saxon. New York, NY: AMS Press.

Williamson, C. (2013/1977). The Old English riddles of the Exeter Book. Chapel Hill: The University of North Carolina Press.

Wojtyś, A. (2009). Suffixal past participle marking in mediaeval English. Anglica, 18, 45-68. 


\section{APPENDIX. OLD ENGLISH WITNESSES TO THE ADJECTIVALLY INFLECTED PAST PARTICIPLE WITH HABBAN}

This appendix lists and describes the texts from the YCOE in which evidence has been found for the adjectival inflection of the past participle with the verb habban. The sources are presented with the following format: Name of text (YCOE file name; Dictionary of Old English (DOE) text name; word count; editor and year of edition).

\begin{tabular}{l}
\hline Alfredian translations \\
\hline Bede's History of the English Church (cobede.o2; 80,767; Miller 1959-1963). \\
\hline Boethius, Consolation of Philosophy (coboeth.o2; 48,443; Sedgefield 1899). \\
Cura Pastoralis (cocura.o2; 68,556; Sweet 1958); Cura Pastoralis (cocuraC; 2,119; Sweet \\
1958).
\end{tabular}

Orosius (coorosiu.o2; Or; 51,020; Bately 1980).

St Augustine's Soliloquies (cosolilo; Solil; 15,856; Endter 1922).

Gregory's Dialogues (cogregdC.o24; GD (C); 91,553; Hecht 1965).

The Bible, Gospels and Apocrypha

Heptateuch (cootest.o3; Gen, Exod, Lev, Num, Deut, Josh, Judg; 59,524; Crawford 1922).

West-Saxon Gospels (cowsgosp.o3; Mt (WSCp), Mk (WSCp), Lk (WSCp), Jn (WSCp); 71,104; Skeat 1871-1887).

The Gospel of Nichodemus (conicodA; Nic (A); 8,197; Cross 1996); The Gospel of Nichodemus (conicodC; Nic (C); 4,629; Hulme 1903-1904); The Gospel of Nichodemus (conicodD; Nic (D); 1,798; Hulme 1903-1904); The Gospel of Nichodemus (conicodE; Nic (E); 1,588; Torkar, from ms. for Dictionary of Old English Project).

Vindicta Salvatoris (covinsal; VSal (1); 3,655; Cross 1996)

\section{Other translations from Latin}

Chrodegang of Metz (cochdrul; ChrodR 1; 18,386; Napier 1971).

Herbarium (coherbar; Lch I (Herb); 22,213; de Vriend 1984).

Bald's Leechbook (colaece.o2; Lch II (1), Lch II (2), Lch II (3); 34,727; Cockayne 18641866).

Apollonius of Tyre (coapollo.o3; ApT; 6,545; Goolden 1958)

\section{Legal prose}

Laws of Cnut (colaw1cn.o3; LawICn; 2,386; Lieberman 1903-16); Laws of Cnut (colaw2cn.o3; LawIICn; 4,761; Lieberman 1903-16). 
Laws of Æthelred V (colaw5atr.o3; LawVAtr; 1,228; Lieberman 1903-16).

Laws of Æthelred VI (colaw6atr.o3; LawVIAtr; 2,096; Lieberman 1903-16).

Laws of Alfred (colawaf.o2; LawAf 1; 3,314; Lieberman 1903-16).

Alfred's Introduction to Laws (colawafint.o2; LawAfEl; 1,966; Lieberman 1903-16). Gerefa (colawger.o34; LawGer; 751; Lieberman 1903-16).

Laws of Ine (colawine.ox2; LawIne; 2,755 Lieberman 1903-16).

Northumbra Preosta Lagu (colawnorthu.o3; LawNorthu; 1,330 Lieberman 1903-16). Laws of

William (colawwllad.o4; LawWlLad; 220; Lieberman 1903-16).

Charters and Wills (codocu1.o1; 1,753; Harmer 1914; Robertson 1956); Charters and Wills (codocu2.o12; 253; Harmer 1914; Robertson 1956); Charters and Wills (codocu2.o2; 1,857; Harmer 1914; Robertson 1956); Charters and Wills (codocu3.o23; 679; Harmer 1914; Robertson 1956); Charters and Wills (codocu3.o3; 7,171; Robertson 1956; Whitelock 1930); Charters and Wills (codocu4; 193; Robertson 1956).

\section{Religious prose}

Martyrology (comart1; Mart 1; 1,300; Herzfeld 1973; Kotzor 1981); Martyrology (comart2; 4,391; Herzfeld 1973; Kotzor 1981); Martyrology (comart3.o23; 25,781; Herzfeld 1973; Kotzor 1981).

Blickling Homilies (coblick.o23; HomS (BlHom 2-7, 9, 11-12); HomU (BlHom 1, 8, 10); LS (BlHom 13-15, 17(MichaelMor), 17(MartinMor), 19); 42,506; Morris 1967).

Vercelli Homilies (coverhom; HomS (ScraggVerc 1, 3, 5, 8, 9, 10, 11, 12, 13, 16, 19, 20); HomU (ScraggVerc 2, 4, 6, 7, 15, 22), HomM (ScraggVerc 14, 21), LS (ScraggVerc 17, 18); 45,674; Scragg 1992); Vercelli Homilies, Homily I (coverhomE; HomS 24.1 (Scragg); 4,463; Scragg 1992); Vercelli Homilies, Homily IX (coverhomL; HomU 15.1 (Scragg); 1,986 Scragg 1992).

The Homilies of Wulfstan (cowulf.o34; WHom; 28,768; Bethurum 1957).

The Seven Sleepers (cosevensl; LS 34; 9,143; Magennis 1994).

\begin{tabular}{l}
\hline Historical prose \\
\hline Anglo-Saxon Chronicle A (cochronA.o23; ChronA; 14,583; Plummer 1965). \\
\hline Anglo-Saxon Chronicle C (cochronC; ChronC; 22,463; Rositzke 1967). \\
\hline Anglo-Saxon Chronicle D (cochronD; ChronD; 26,691; Classen and Harmer 1926). \\
$\begin{array}{l}\text { Anglo-Saxon Chronicle E (Peterborough Chronicle) (cochronE.o34; ChronE; 40,641; } \\
\text { Plummer 1965). }\end{array}$
\end{tabular}

\section{Alfrician prose}

Ælfric's Catholic Homilies I (cocathom1.o3; ÆCHom I; 106,173; Clemoes 1997).

Ælfric's Catholic Homilies II (cocathom2.o3; ÆCHom II; 98,583; Godden 1979).

Ælfric's Homilies Supplemental (coaelhom.o3; ÆHom; 62,669; Pope 1968).

Ælfric's Lives of Saints (coaelive.o3; ÆLS; 100,193; Skeat 1966). 